\title{
Influence of School-based Factors on Teacher Turnover Intentions: A Case of Public Secondary Schools in Rachuonyo North Sub-County, Kenya
}

\author{
Ruth Achieng Ayall* \\ ORCID: https://orcid.org/0000-0001-6848-9218 \\ Faculty of Education \\ Tom Mboya University College, Kenya \\ Boke Joyce Wambura, PhD \\ ORCID: https://orcid.org/0000-0001-8509-5771 \\ Faculty of Education \\ Tom Mboya University College, Kenya \\ Prof. Enose M.W. Simatwa, PhD \\ ORCID: https://orcid.org/0000-0003-4057-0983 \\ Faculty of Education \\ Tom Mboya University College, Kenya \\ *Corresponding Mail: ruth.ayall56@gmail.com
}

\begin{abstract}
Copyright resides with the author(s) in terms of the Creative Commons Attribution CC BY-NC 4.0. The users may copy, distribute, transmit and adapt the work, but must recognize the author(s) and the East African Journal of Education and Social Sciences
\end{abstract}

\begin{abstract}
This study sought to establish school-based factors that influence teacher turnover intention among secondary schools in Rachuonyo North Sub County, Kenya. While a total of 390 secondary school teachers constituted the population, Fisher's model guided the sampling of 132 teachers as respondents. The questionnaire was presented to two experts who examined it and advised on what to do to improve it. A pilot test was conducted by administering the questionnaire to respondents not involved in the study and the Cronbach's Alpha of 0.7 and above was obtained which allowed the researchers to proceed with data collection. The researchers obtained permission from NACOSTI and the Director of Education at Homabay County before going to the field to collect data. The study concludes that most of items in the questionnaire had either low or very low influence toward teachers' turnover intention. School-based factors that had high influence included poor communication strategies and frustration. School management, especially the principals and deputy Principals, have a role in creating attractive environments by treating teachers professionally and ethically, maintaining effective communication and offering such incentives as meals and snacks in order to prevent potential turnover intentions.
\end{abstract}

Keywords: School based factors; Turnover Intentions; Public Secondary; Rachuonyo North Sub County

How to cite: Ayall, R. A., Wambura, B. J. and Simatwa, E. M. W. (2021). Influence of School-based Factors on Teacher Turnover Intentions: A Case of Public Secondary Schools in Rachuonyo North Sub-County, Kenya. East African Journal of Education and Social Sciences 2(4), 125-129. Doi: https://doi.org/10.46606/eajess2021v02i04.0136.

\section{Introduction}

Turnover is defined as a deliberate, willful and conscious decision of an employee to leave the organization (Tett \& Meyer, 1993). Turnover intention is further described as the employee's desire to resign and seek employment in other organizations (Jung, Yoon \& Kim, 2012). As school- 
based factors contribute to teachers' well-being, teachers who are satisfied with school related factors demonstrate a more substantial job commitment, provide better learning support to students and are less likely to leave their profession (Blömeke, Houang, Hsieh, \& Wang, 2017). On the contrary, teacher turnover rates lead to shortage of qualified educators (Ingersoll, 2017). The negative consequences for teachers' departure include poor teaching quality due to reduced task force (Toropova, Myrberg \& Johnasson, 2021).

Teacher turnover can be indicated by migration and attrition. While migration is teachers' movement to other schools, attrition pertains to leaving the profession. Studies indicate that teacher turnover threatens performance in examinations (Ingersoll, 2001), disrupts instructional programs (Johnson, Kraft, and Papay, 2012) and leads to low-quality education due to weakened quality of teaching (Loeb, Darling-Hammond \& and Luczak, 2005). According to Nyambura (2011), teacher turnover is due to inadequate or dilapidated physical resources and poor remuneration. Therefore, it is important for school stakeholders to do what is required in response to this challenge so as to reduce the turnover rates in schools.

Previous studies have highlighted on factors influencing teachers' intention to leave their profession. Yan (2021), for instance, researched on the influence of school principals' working conditions on their turnover probability in Bloomington, USA. The study utilized the National Centre for Education Statistics data to establish how working conditions are associated with principals' turnover. The study established that principals with higher salaries and beneficial job contracts were less likely to have turnover intentions. Additionally, principals working in schools with high concentrations of students with excellent discipline had a lower risk of moving to another school. These results assisted policymakers in providing favorable and positive working conditions that supported the retention of school principals. Sone (2021) interviewed thirty-seven teachers from fourteen schools in Cameroon using semi-structured interviews and established that school leadership, remuneration, workload and cultural practices influenced teachers' attrition.

In Kenya, Ekabu, Kalai and Nyagah (2018) investigated on teachers' working conditions and their relationship with turnover intentions. The study established that poor working conditions for teachers led to low motivation which influenced intention to leave. The study recommended that various education stakeholders at the national and county levels should consider improving teachers' working condition in order to reduce chances for their departure. Similarly, Njung'e (2015) studied on job satisfaction and its effect on turnover intention among public secondary schools in Gatanga District, Kenya. The study established that teachers in the district were not satisfied with most of their working environment and were planning to quit teaching. Particularly, inadequate salary was identified as the main reason for their intention to leave. Those planning to transfer to other schools cited dissatisfaction with the schools' leadership style and motivation strategies as key factors that contributed to their intention to depart from their current schools.

The study of Mugo and Guyo (2018) with public secondary school teachers in Embu County, Kenya, detected high labour turnover intentions. Factors contributing to the high turnover included lack of recognition and involvement during decision making, low salaries, increased workload and lack of time for professional-development. Obungu, Njuguna, and Itegi (2021) investigated on the effect of working conditions of science teachers' retention among public secondary schools in Kisumu. The study established that appropriate working conditions enhanced the retention of Science teachers. The study recommended that secondary school Principals should improve school-based factors by providing personal protective equipment and appropriate infrastructure. The study of Muriithi (2020) reported that attractive compensation, appropriate working environment and effective leadership significantly influenced teachers' retention. The study recommends that schools should strive to improve compensation and to provide attractive working conditions in order to retain teachers. Based on the background of this study, the researchers investigated on school-based factors influencing teacher turnover intentions among public secondary schools in Rachuonyo North Subcounty in Kenya.

\section{Research Methodology}

\section{Research Design}

This study employed the descriptive survey design to establish how teacher turnover intentions among public secondary schools in Rachuonyo North Sub-County, Kenya, are influenced by schoolbased factors. 


\section{Population and Sampling}

A total of 390 secondary school teachers constituted the population of the study. Fisher's model guided the sampling procedure to determine 132 teachers as respondents. Table 1 provides the demographics of respondents which indicate that the sampling considered various characteristics of respondents.

Table 1: Demographics of Teachers

\begin{tabular}{|c|c|c|}
\hline Gender & Frequency & Percent \\
\hline Female & 71 & 53.8 \\
\hline Male & 60 & 45.5 \\
\hline Missing & 1 & 1.2 \\
\hline Total & 132 & 100 \\
\hline \multicolumn{3}{|l|}{ Age Bracket } \\
\hline $20-30$ & 30 & 22.7 \\
\hline $31-40$ & 38 & 28.8 \\
\hline $41-50$ & 37 & 28 \\
\hline $51-60$ & 26 & 19.7 \\
\hline Total & 132 & 100.0 \\
\hline \multicolumn{3}{|l|}{ Marital status } \\
\hline Married & 84 & 63.6 \\
\hline Single & 29 & 22.0 \\
\hline Divorced & 10 & 7.6 \\
\hline Widow /widower & 8 & 6.1 \\
\hline Total & 132 & 100.0 \\
\hline \multicolumn{3}{|l|}{ Qualifications } \\
\hline Degree & 93 & 707 \\
\hline Diploma & 10 & 7.6 \\
\hline Masters & 28 & 21.2 \\
\hline Total & 132 & 100.0 \\
\hline \multicolumn{3}{|l|}{ Teaching } \\
\hline \multicolumn{3}{|l|}{ Experience } \\
\hline $0-5$ years & 34 & 25.8 \\
\hline $6-10$ years & 26 & 19.7 \\
\hline $11-15$ years & 28 & 21.2 \\
\hline $16-20$ years & 18 & 13.6 \\
\hline $21-25$ years & 12 & 9.1 \\
\hline $26-30$ years & 11 & 8.3 \\
\hline Above 31 years & 2 & 1.5 \\
\hline Total & 132 & 100 \\
\hline
\end{tabular}

\section{Statistical Treatment of Data}

This study used the quantitative approach. Data was categorized, coded and entered into a computer to enable the analysis. After data cleaning, descriptive statistics in terms of mean scores, frequencies and percentages were run and presented through tables.

\section{Validity and Reliability}

The questionnaire was presented to two experts from the Department of Educational Policy and Management at the Tom Mboya University College. The experts examined it and advised on what to do to improve it. A pilot test was conducted by administering the questionnaire to respondents not involved in the final study and the Cronbach's Alpha of 0.7 and above was obtained which allowed the researchers to proceed with data collection.

\section{Ethical Considerations}

As ethical issues in research are related to volunteerism, confidentiality and anonymity, the researchers obtained permission from NACOSTI and the Director of Education at Homabay County before going to the field to collect data. The researchers further obtained informed consent from potential participants. Confidentiality, their right to privacy and their anonymity were also considered. Finally, researchers ensured that the final report represented what was reported by the respondents.

\section{Results and Discussions}

Since the major intention of this study was to establish factors that influence teachers' intention to experience turnover, teachers were given 18 items in the questionnaire as seen in table 2 to indicate their perception. The data was analysed through descriptive statistics to determine the mean score for each statement in the questionnaire whereby $1.00-1.44=$ no influence, $1.45-2.44=$ very low influence, $2.45-3.44=$ Low influence, $3.45-$ $4.44=$ high influence and $4.45-5.00=$ very high influence.

\section{Very Low}

Table 2 (p. 128) indicates that professional ethics at the school level and working relationship with the school Principal were perceived to have very low influence to turnover intention. The findings are similar to what Mugo and Guyo (2018) established that the application of professional ethics at school level is translated to mean when teachers are provided with appropriate environments for selfdevelopment, when they have a fair and effective reward system and opportunities for professional development, these factors had very low influence on turnover intentions.

\section{Low}

Table two further indicates that 13 items were perceived by teachers to have low influence toward turnover intentions. These included collegiality and teamwork in the school, school working conditions, involvement in decision making at school, student's behavior and discipline, political interference, students performance, staff welfare, lack of induction and monitoring in the school system, resources and facilities in the school, involvement of 
staff in decision making, Principal and deputy head teachers treatment of teachers, cooperation of teachers and class size. Saidu (2021) cited motivation, improving hygiene factors such as interpersonal relations, remuneration, administrative and leadership relationships, school policies and selected working conditions as among leadership strategies that can be used to reduce turnover. Therefore, the lowly perceived influence of these factors is in harmony with previous studies.

Table 2: Teachers' Ratings on Influence of School-Based Factors on Turnover Intention

\begin{tabular}{llcc}
\hline SN & \multicolumn{1}{c}{ Factor } & Mean & Interpretation \\
\hline 1 & Professional ethics at the school level & 2.08 & Very Low \\
2 & Working relationship with the principal & 2.39 & Very Low \\
3 & Collegiality and teamwork in the school & 2.55 & Low \\
4 & Unfriendly school working conditions & 2.58 & Low \\
5 & Involvement in decision making at school & 2.66 & Low \\
6 & Student's behaviour and discipline & 2.80 & Low \\
7 & Political interference in school management & 2.82 & Low \\
8 & Students performance & 2.93 & Low \\
9 & Staff welfare & 2.95 & Low \\
10 & Lack of induction and monitoring in the school system & 3.10 & Low \\
11 & Resources and facilities in the school & 3.12 & Low \\
12 & Involvement of staff in decision making & 3.13 & Low \\
13 & Principal and deputy head teachers treatment of teachers & 3.15 & Low \\
14 & Cooperation of teachers & 3.16 & Low \\
15 & Class size & 3.32 & Low \\
16 & Communication network in the school & 3.54 & High \\
17 & Frustration in the school when given opportunity to excel & 3.6 & High \\
18 & Delegation of responsibilities and duties by the principal & 3.78 & High \\
\hline
\end{tabular}

\section{High}

The last three items in the questionnaire were perceived to have high influence toward teachers' turnover intention. These were communication factor, frustration and delegation of responsibilities and duties by the principal, which means that respondents were uninterested with additional duties delegated by the school leadership. Respondents further considered frustration and poor communication as factors that may propel teacher's possibility to experience attrition or turnover. When communication is unclear and ambiguous, wrangles and collision of interests is likely to take place. This may kill teacher's morale and job commitment and even cause turnover. Similarly, Chen, Tsou, Chou, and Ciou, (2019) found a negative relationship between measures of promotional frustration and employees' attitude towards the company implying that employees were having negative attitude toward the company, thus possibility to experience turnover if employees are given chances for shifting from their organization.

\section{Conclusions and Recommendations}

The study concludes that most of items in the questionnaire had either low or very low influence toward teachers' turnover intention. School-based factors that had high influence on teacher turnover intentions included poor communication strategies and frustration. School management, especially the principals and deputy Principals, have a role in creating attractive environments by treating teachers professionally and ethically, maintaining effective communication and offering such incentives as meals and snacks in order to prevent potential turnover intentions.

\section{References}

Blömeke, S., Houang, R., Hsieh, F. J., \& Wang, T. Y. (2017). Effects of job motives, teacher knowledge and school context on beginning teachers' commitment to stay in the profession: A longitudinal study in Germany, Taiwan, and the United States. In G. K. LeTendre \& M. Akiba (Eds.), International handbook of teacher quality and policy (pp. 374-387). London: Routledge. [Crossref], [Google Scholar].

Ekabu, P. K, Nyagah, G., \& Kalai, J. M. (2018). Influence of promotional prospects on turnover intentions of Public Secondary School Teachers in Meru County. European Scientific Journal, 14, (25), 27-36.

Ingersoll, R. (2017). Misdiagnosing America's teacher quality problem. In G. K. LeTendre \& M. Akiba (Eds.), International handbook 
of teacher quality and policy (pp. 79-96). London: Routledge. [Crossref], [Google Scholar]

Ingersoll, R. M. (2001). Teacher turnover and teacher shortages: An organizational analysis. American educational research journal, 38(3), 499-534.

Johnson, S.M., Kraft, M.A., \& Papay, J.P. (2012). How context matters in high-need schools. The effects of teachers working conditions on their professional satisfaction and their students' achievements. Teachers College Record, 114(10), 1-39

Jung, H. S., Yoon, H. H., \& Kim, Y. J. (2012). Effects of Culinary Employees' Role Stress on Burnout and Turnover Intention in Hotel Industry: Moderating Effects on Employees' Tenure. Service Industry Journal. 32(13):2145-2165.

Loeb, S., Darling-Hammond, L., \& Luczak, J. (2005). How teaching conditions predict teacher turnover in California schools. Peabody journal of education, 80(3), 44-70

Mugo, E. W. \& Guyo, W., (2018). Factors contributing to labour turnover among public secondary school teachers in Kenya: a case of Embu County. International Journal of Economics, Commerce, and Management. Vol. VI, (363-384). ISSN 2348-0386.

Muriithi, P.M. (2020). Motivational factors influencing teacher retention in private primary schools in Murang'a diocese. Masters of Science in Education Management, Strathmore University School of Humanities and Social Sciences.

Njung'e, A.M., (2015). Impact of Job Satisfaction on Turnover Intentions among Teachers in Public Secondary Schools in Gatanga District, Murang'a County, Kenya.
Nyambura, K., J. (2011). Factors influencing teachers turnover in public secondary schools in Makadara district, Nairobi province, Kenya. A Research Project Submitted to the School of Business in Partial Fulfillment for the award of degree of Master of Business Administration of Kenyatta University Kenya

Obungu, E. O., Njuguna, F. W., \& Itegi, F. M. (2021). Working conditions on retention of science teachers in public secondary schools in Kisumu County, Kenya. Journal of Educational Research in Developing Areas, 2(1), 63-75.

Saidu, S. O. (2021). Leadership Strategies Used to Reduce Turnover in Turnaround Settings. Unpublished Doctoral Dissertation, Walden University.

Sone, C.N. (2021). An Exploration of Teacher Attrition and Retention in Private Secondary Schools in Cameroon. Thesis Submitted in partial fulfilment of the Degree of Doctor of Philosophy to Cardiff Metropolitan University.

Tett, R. P., \& Meyer, J. P. (1993). Job satisfaction, organisational commitment, turnover intention, and turnover: path analyses based on meta-analytic findings. Personnel Psychology, 46 (2), 259-293.

Toropova, A., Myrberg, E. \& Johansson, S. (2021) Teacher job satisfaction: the importance of school working conditions and teacher characteristics., Educational Review, 73:1, 71-97, DOI: 10.1080/00131 911.201 9.1705247 .

Yan, Y. (2021). The Influence of Working Conditions on Principal Turnover in K-12 Public Schools Educational Administration Quarterly 2020, Vol. 56(1) 89-122.DOI: 10.1177/0013161X19840391.journals.sage pub.com/home/eaq. 